\title{
New Antiviral Agents for Hepatitis C
}

\author{
Jean-Michel Pawlotsky ${ }^{1,2}$
}

\author{
Addresses: ${ }^{1}$ National Reference Center for Viral Hepatitis B, C and D, Department of Virology, Henri Mondor Hospital, University of Paris-Est, \\ France; ${ }^{2}$ INSERM U955; 51 avenue du Maréchal de Lattre de Tassigny, 94010 Créteil, France \\ Email: jean-michel.pawlotsky@hmn.aphp.fr \\ FI000 Biology Reports 2012, 4:5 (doi:10.34I0/B4-5) \\ This is an open-access article distributed under the terms of the Creative Commons Attribution-Non Commercial License \\ (http://creativecommons.org/licenses/by-nc/3.0/legalcode), which permits unrestricted use, distribution, and reproduction in any medium, \\ provided the original work is properly cited. You may not use this work for commercial purposes. \\ The electronic version of this article is the complete one and can be found at: http://fl000.com/reports/b/4/5
}

\begin{abstract}
Approximately I20-130 million individuals are chronically infected with hepatitis C virus (HCV) worldwide, although it is curable by therapy. Until recently, treatment of chronic hepatitis $C$ was based on the combination of pegylated interferon- $\alpha$ and ribavirin. A number of models have been developed to study the HCV lifecycle and screen for potential HCV inhibitors. They led to the development of antiviral agents that specifically target a viral function (direct acting antivirals), and host-targeted agents that inhibit HCV replication. Direct acting antivirals in clinical development include NS3-4A protease inhibitors (two of which, telaprevir and boceprevir, have recently been approved for treatment of HCV genotype I infection in combination with pegylated interferon- $\alpha$ and ribavirin), nucleoside/nucleotide analogue and non-nucleoside inhibitors of HCV RNA-dependent RNA polymerase, and NS5A inhibitors. Hosttargeted agents include cyclophilin inhibitors. This article describes the direct acting antivirals and hosttargeted agents that have recently been approved or have been tested in HCV-infected patients and discusses their two current paths of clinical development: with or without interferon- $\alpha$.
\end{abstract}

\section{Introduction}

Hepatitis C virus (HCV) was discovered in 1989 [1]. It was found to be responsible for the vast majority of so-called chronic non-A, non-B hepatitis and cryptogenetic liver diseases [2-4]. In adults, acute HCV infection leads to chronic infection in approximately $80 \%$ of cases. Chronic $\mathrm{HCV}$ infection is responsible for chronic hepatitis, which is complicated by cirrhosis in approximately $20 \%$ of cases. Patients with cirrhosis are exposed to life-threatening complications, including end-stage liver disease, esophageal varices hemorrhage and the development of hepatocellular carcinoma, which occurs at an incidence of $4 \%$ 5\% per year in these patients [5]. Approximately 120-130 million individuals are chronically infected with $\mathrm{HCV}$ worldwide [6]. Chronic HCV infection has become the leading cause of hepatocellular carcinoma (primary liver cancer) and the first indication of liver transplantation in industrialized countries [5]. Six genotypes (1 to 6) and a number of subtypes have been described. Genotype 1 (subtypes $1 \mathrm{a}$ and $1 \mathrm{~b}$ ) is by far the most frequent genotype worldwide [7].
Unlike other known chronic viral infections, HCV infection is curable by therapy. Cure of infection is characterized by the "sustained virological response", defined as undetectable HCV RNA in peripheral blood by means of sensitive molecular biology-based techniques. Until recently, treatment of chronic hepatitis $\mathrm{C}$ was based on the combination of a pegylated form of interferon (IFN)- $\alpha$ (pegylation improves the pharmacokinetic and pharmacodynamic properties and enhances the antiviral potency of IFN) and ribavirin [8-10]. This combination cures approximately $80 \%$ of infections in patients infected with HCV genotypes 2 or 3, but only $40 \%-50 \%$ in patients infected with genotypes 1 or 4 . This emphasizes the need for more efficient antiviral strategies.

Over the past 10 years, a number of models have been developed to study the HCV lifecycle and screen for potential HCV inhibitors [11]. These models include cellfree enzyme assays for the HCV NS3-4A protease and RNA-dependent RNA polymerase, hepatoma cell lines harboring subgenomic and genomic replicons (nucleic 
acids capable of autonomous replication), an infectious cell culture system (limited to genotype 2a), and humanized mouse models infectable by HCV. They led to the development of antiviral agents that specifically target a viral function, now collectively termed "direct acting antivirals". In addition, "host-targeted agents" that inhibit HCV replication are also in development. This article describes the direct acting antivirals that have recently been approved and direct acting antivirals and host-targeted agents that have been tested in HCV-infected patients and discusses their current paths of clinical development: with or without IFN- $\alpha$.

\section{New HCV drugs in development}

In principle, every step of the HCV lifecycle, including receptor binding, endocytosis, fusion, uncoating, translation, polyprotein processing, RNA replication, virion assembly, maturation, transport and release, can be a target for new anti-HCV drugs [12]. Thus far, drugs targeting two major steps of the HCV lifecycle have reached clinical development. They include inhibitors of the HCV NS3-4A protease that block polyprotein processing and several drug families that block viral replication, including nucleoside/nucleotide inhibitors of the HCV RNAdependent RNA polymerase, non-nucleoside inhibitors of the HCV RNA-dependent RNA polymerase, and inhibitors of the NS5A viral protein which plays a regulatory role in replication. Host-targeted agents that inhibit the host cell protein cyclophilin A, a protein required to interact with the replication complex for efficient viral genome production, are also in clinical development. Table 1 summarizes the drugs that have been tested in clinical trials and for which results have been published or presented at medical meetings as of November 2011.

\section{Barrier to resistance of HCV drugs}

Like antiretroviral drugs, HCV direct acting antivirals have been shown to select drug-resistant viral variants, the outgrowth of which is responsible for virological breakthrough and disease progression [13]. In vivo, the "barrier to resistance" of an HCV drug is influenced by three parameters: (a) the "genetic barrier to resistance" of the drug, defined as the number of amino acid substitutions needed for a viral variant to acquire full resistance to the

Table I. New drugs that have reached clinical development for treating chronic hepatitis $\mathbf{C}$ (/r means boosted by ritonavir)

\begin{tabular}{|c|c|c|}
\hline Drug & Manufacturer & Phase \\
\hline \multicolumn{3}{|c|}{ NS3-4A protease inhibitors } \\
\hline Telaprevir & Vertex \& Janssen & Approved \\
\hline Boceprevir & Merck & Approved \\
\hline TMC435 & Janssen & III \\
\hline $\mathrm{BI} 20 \mathrm{I} 335$ & Boehringer-Ingelheim & III \\
\hline Danoprevir/r & Roche/Genentech & II \\
\hline Vaniprevir & Merck & II \\
\hline Narlaprevir/r & Merck & II \\
\hline Asunaprevir & Bristol-Myers Squibb & II \\
\hline GS-9256 & Gilead & II \\
\hline GS-945 I & Gilead & II \\
\hline ABT $-450 / r$ & Abbott & II \\
\hline ACH-I625 & Achillion & II \\
\hline $\mathrm{ACH}-2684$ & Achillion & $\mathrm{lb}$ \\
\hline MK-5I72 & Merck & II \\
\hline \multicolumn{3}{|c|}{ Nucleoside/nucleotide analogue inhibitors of HCV RNA-dependent RNA polymerase } \\
\hline PSI-7977 & Pharmasset/Gilead & III \\
\hline Mericitabine & Roche/Genentech & II \\
\hline IDXI84 & Idenix & II \\
\hline PSI-938 & Pharmasset/Gilead & II \\
\hline INX-I89 & Inhibitex & $\mathrm{lb}$ \\
\hline \multicolumn{3}{|c|}{ Non-nucleoside inhibitors of HCV RNA-dependent RNA polymerase } \\
\hline Tegobuvir & Gilead & II \\
\hline Filibuvir & Pfizer & II \\
\hline Setrobuvir & Roche/Genentech & II \\
\hline $\mathrm{BI} 207 \mathrm{I} 27$ & Boehringer-Ingelheim & II \\
\hline ABT-333 & Abbott & II \\
\hline VX-222 & Vertex & II \\
\hline TMC-647055 & Janssen & $\mathrm{lb}$ \\
\hline \multicolumn{3}{|l|}{ NS5A inhibitors } \\
\hline Daclatasvir & Bristol-Myers Squibb & II \\
\hline PPI-46I & Presidio & $\mathrm{lb}$ \\
\hline GS-5885 & Gilead & $\mathrm{lb}$ \\
\hline GSK2336805 & GlaxoSmithKline & $\mathrm{lb}$ \\
\hline \multicolumn{3}{|c|}{ Cyclophilin inhibitors } \\
\hline Alisporivir & Novartis & III \\
\hline SCY-465 & Scynexis & II \\
\hline
\end{tabular}


drug in question (if a single substitution is sufficient to confer high-level resistance, the drug is considered to have a low genetic barrier to resistance, while the need for three or more substitutions represents a high genetic barrier); (b) the "in vivo fitness" of the resistant viral variant population, defined as its ability to survive and grow in the replicative environment; and (c) drug exposure, defined as the drug concentration achieved in vivo relative to the $50 \%$ and $90 \%$ inhibitory concentrations (in enzyme assays) and efficient concentrations (in cellular assays) [13]. HCV drugs in development can be split into two groups according to their barrier to resistance, including drugs with a low barrier to resistance, and drugs with a high barrier to resistance.

\section{HCV drugs with a low barrier to resistance}

HCV drugs with a low barrier to resistance include the following direct acting antivirals: first-generation NS3-4A protease inhibitors, non-nucleoside inhibitors of HCV RNA-dependent RNA polymerase and NS5A inhibitors.

A large number of NS3-4A protease inhibitors have reached clinical development, including two drugs, telaprevir and boceprevir (Table 1), that have recently been approved for use in combination with pegylated IFN- $\alpha$ and ribavirin in patients infected with genotype 1. NS3-4A protease inhibitors have closely related chemical structures. They inhibit viral replication by 3.5 to $4.5 \mathrm{Log}$ international units (IU)/mL when administered alone for a few days (one log reduction means that the viral level has been divided by 10, $2 \log$ by 100, etc). Telaprevir and boceprevir are active against genotypes 1 and 2 only, whereas other protease inhibitors have broader genotype coverage; however, none of the first-generation NS3-4A protease inhibitors are active against genotype 3. A large number of amino acid substitutions conferring resistance to protease inhibitors have been shown to pre-exist at generally low levels in infected patients and are selected within a few days to weeks on drug monotherapy [13]. Different resistance profiles have been reported for subtypes 1a and 1b. Second-generation NS3-4A protease inhibitors, such as MK-5172 or ACH-2684 (Table 1), are expected to have broader genotypic coverage and higher barriers to resistance.

In contrast to protease inhibitors, non-nucleoside inhibitors of HCV RNA-dependent RNA polymerase are a heterogeneous group of drug families targeting one of four allosteric sites at the surface of the viral enzyme (Table 1). Their antiviral action is thus far restricted to HCV genotype 1. Different non-nucleoside inhibitors may have different antiviral potencies and select amino acid substitutions conferring resistance that is generally, but not always, located in close vicinity to their target site.
Extensive cross-resistance has been reported between drugs targeting the same site, and cross-resistance can also occur between drugs targeting different sites.

NS5A inhibitors are potent antiviral drugs that block the function of the NS5A protein through an, as yet, unclear mechanism (Table 1). They have broad genotypic coverage, but a low barrier to resistance, with the highest levels of resistance conferred by single amino acid substitutions in subtype 1a.

\section{New HCV drugs with a high barrier to resistance}

HCV drugs with a high barrier to resistance include nucleoside/nucleotide analogues and host-targeted agents, such as cyclophilin inhibitors. Nucleoside/nucleotide analogues target the catalytic site of the RNAdependent RNA polymerase. Several nucleoside and nucleotide analogues have reached clinical development, including purine and pyrimidine analogues. They are effective on all known genotypes and subtypes. Although these drugs have a low "genetic barrier" to resistance (as one single amino acid substitution is sufficient to confer resistance to the drug), these amino acid substitutions alter the conformation of the enzyme catalytic site. Thus, resistant variants exhibit low fitness and are not clinically meaningful. In this respect, nucleoside/nucleotide analogues have a high "barrier" to resistance in vivo, as resistant viral populations on single drug administration grow very slowly with virological breakthrough eventually occurring after months of treatment.

Cyclophilin A plays an important role in the HCV replication cycle by binding to both NS5A and the RNAdependent RNA polymerase within the viral replication complex. Blocking cyclophilin peptidyl-prolyl cis-trans isomerase enzyme activity results in a significant inhibition of HCV replication both in vitro and in vivo, through molecular mechanisms that remain unclear. Because their target is a host protein, cyclophilin inhibitors have broad genotypic coverage and a favorable resistance profile. Amino acid substitutions in the NS5A protein can be selected by these drugs, but they confer low-level resistance and the corresponding variants exhibit low fitness.

\section{Newly approved NS3-4A protease inhibitors}

The first available direct acting antivirals for clinical development in patients infected with HCV genotype 1 were the NS3-4A protease inhibitors telaprevir and boceprevir. Due to their low barrier to resistance, it soon appeared that they could not be used alone and should be combined with other compounds with potent antiviral properties and no cross-resistance with the protease inhibitors. Only pegylated IFN- $\alpha$ and ribavirin were 
available for combination in Phase II and III clinical trials. It soon became apparent that ribavirin was also needed to improve the cure rates in combination with pegylated IFN- $\alpha$ and a protease inhibitor [14]. In 2011, the results of several Phase III trials have led to the approval of both telaprevir (Incivek, Vertex Pharmaceuticals, in the US; Incivo, Janssen, in Europe) and boceprevir (Victrelis, Merck) in combination with pegylated IFN- $\alpha$ and ribavirin [15-18]. Complex treatment algorithms have been issued in the US Food and Drug Administration and European Medicines Agency labels, which substantially differ between the two protease inhibitors (Tables 2 and 3). Treatment duration must be tailored to the severity of liver disease, prior virological response to pegylated IFN- $\alpha$ and ribavirin in previously treated patients, and the virological response during therapy (response-guided therapy). Sustained virological response rates in the range of $66 \%$ to $75 \%$ have been achieved in treatment-naïve patients in Phase III trials, significantly higher than with pegylated IFN- $\alpha$ and ribavirin alone $[16,18]$. In previously treated patients, the results strongly depended on the prior response to pegylated IFN- $\alpha$ and ribavirin, with sustained virological response rates of the order of $30 \%$ in prior null responders and up to approximately $85 \%$ in prior responder-relapsers [15,17].

In addition to the complexity of the approved treatment regimens, the new triple combination therapies raise a number of issues.

\section{(a) They are restricted to HCV genotype 1.}

(b) The addition of a third drug to pegylated IFN- $\alpha$ and ribavirin is associated with additional, and eventually severe, side effects. The principal adverse reactions associated with telaprevir are anemia, pruritus and rash $[17,18]$. Rash is observed in approximately half of cases. It is generally benign and responds well to topical corticosteroids; however, severe cases have been reported in clinical trials, including occasional cases of StevensJohnson syndrome and Drug Reaction with Eosinophilia and Systemic Symptoms (DRESS) syndrome. These complications can be life-threatening and impose rapid treatment interruption. Therefore, telaprevir therapy requires strict adherence to the rash management plan, in close collaboration with experienced dermatologists. Boceprevir administration is associated with anemia that aggravates hemolytic anemia due to ribavirin and dysgueusia $[15,16]$.

(c) Selection of viral variants that are resistant to the protease inhibitor is an inevitable consequence of treatment failure, i.e. the failure to eradicate the virus on triple combination therapy. Such failure is due to an inadequate response to pegylated IFN- $\alpha$ and ribavirin, which does not prevent outgrowth of resistant variants selected by the protease inhibitor [13]. After treatment cessation, resistant viral populations progressively decrease in proportion and are no longer detectable with population sequencing after a period of a few months to two years [19-21]. Selection of resistant $\mathrm{HCV}$ variants does not appear to have a negative impact on the outcome of liver disease. Theoretically, it should not compromise the chance for a subsequent cure with another drug regimen.

(d) The addition of a protease inhibitor substantially increases the cost of therapy, raising issues regarding screening policies and access to care.

\section{Two paths of clinical development of HCV direct acting antivirals}

Issues raised by the recent approval of telaprevir and boceprevir in combination with pegylated IFN- $\alpha$ and ribavirin emphasize the need for alternative therapeutic strategies that ensure broader genotypic coverage, better efficacy, better tolerance and limited selection of resistant

Table 2. Telaprevir label (US and Europe)

\begin{tabular}{|c|c|c|c|}
\hline \multirow[b]{2}{*}{ Patients } & \multicolumn{2}{|c|}{ HCV RNA } & \multirow[b]{2}{*}{ Treatment } \\
\hline & Week 4 & Week 12 & \\
\hline \multirow[t]{2}{*}{$\begin{array}{l}\text { Treatment-naïve and responder- } \\
\text { relapsers }\end{array}$} & Undetectable & Undetectable & $\begin{array}{l}\text { Treat with } 3 \text { drugs for } 12 \text { weeks } \\
\text { Continue with pegylated IFN- } \alpha \text { and } \\
\text { ribavirin until week } 24\end{array}$ \\
\hline & Detectable $(\leq 1000 \mathrm{IU} / \mathrm{mL})$ & and/or Detectable $(\leq 1000 \mathrm{IU} / \mathrm{mL})$ & $\begin{array}{l}\text { Treat with } 3 \text { drugs for } 12 \text { weeks } \\
\text { Continue with pegylated IFN- } \alpha \text { and } \\
\text { ribavirin until week } 48\end{array}$ \\
\hline $\begin{array}{l}\text { Partial responders and null } \\
\text { responders }\end{array}$ & All patients & & $\begin{array}{l}\text { Treat with } 3 \text { drugs for } 12 \text { weeks } \\
\text { Continue with pegylated IFN- } \alpha \text { and } \\
\text { ribavirin until week } 48\end{array}$ \\
\hline
\end{tabular}

Telaprevir is administered at day 0 and for 12 weeks at the dose of $750 \mathrm{mg}$ every $7-9$ hours with fatty food, in combination with either pegylated IFN- $\alpha 2 \mathrm{a}$ ( $180 \mu \mathrm{g} /$ week subcutaneously) or pegylated IFN- $\alpha 2 \mathrm{~b}$ (I.5 $\mu \mathrm{g} / \mathrm{kg} /$ week subcutaneously), and ribavirin $(0.8$ to I.2 g/day according to body weight). Futility rule: stop therapy if HCV RNA >1000 IU/mL at week 4 or 12 or detectable at week 24. Abbreviations: IFN, interferon. 
Table 3. Boceprevir labels (US and Europe)

\begin{tabular}{|c|c|c|c|}
\hline \multirow[b]{2}{*}{ Patients } & \multicolumn{2}{|c|}{ HCV RNA } & \multirow[b]{2}{*}{ Treatment } \\
\hline & Week 4 & Week I2 & \\
\hline \multirow[t]{2}{*}{ Treatment-naïve without cirrhosis } & Undetectable & Undetectable & Treat with 3 drugs until week 28 \\
\hline & Detectable & Undetectable & $\begin{array}{l}\text { Treat with } 3 \text { drugs until week } 36 \\
\text { Continue with pegylated IFN- } \alpha \text { and ribavirin } \\
\text { until week } 48\end{array}$ \\
\hline \multirow[t]{2}{*}{ Responder-relapsers and partial responders without cirrhosis } & Undetectable & Undetectable & $\begin{array}{l}\text { US: Treat with } 3 \text { drugs until week } 36 \\
\text { Europe: Treat with } 3 \text { drugs until week } 36 \\
\text { Continue with pegylated IFN- } \alpha \text { and ribavirin } \\
\text { until week } 48\end{array}$ \\
\hline & Detectable & Undetectable & $\begin{array}{l}\text { Treat with } 3 \text { drugs until week } 36 \\
\text { Continue with pegylated IFN- } \alpha \text { and ribavirin } \\
\text { until week } 48\end{array}$ \\
\hline Null responders and all cirrhotics & All patients & & Treat with 3 drugs until week 48 \\
\hline
\end{tabular}

Boceprevir is administered after 4 weeks of "lead-in" with pegylated IFN- $\alpha$ and ribavirin alone at the dose of $800 \mathrm{mg}$ every 7-9 hours with food, in combination with either pegylated IFN- $\alpha 2 \mathrm{~b}(\mathrm{I} .5 \mathrm{\mu g} / \mathrm{kg} /$ week subcutaneously) or pegylated IFN- $\alpha 2 \mathrm{a}$ (I80 $\mathrm{\mu g} /$ week subcutaneously), and ribavirin $(0.8$ to I.4 g/day according to body weight). Futility rule: stop therapy if $\mathrm{HCV}$ RNA $>100 \mathrm{IU} / \mathrm{mL}$ at week 12 or detectable at week 24. Abbreviations: IFN, interferon.

HCV variants. The clinical development of new HCV drugs currently follows two paths, according to whether or not pegylated IFN- $\alpha$ is included in the drug combination.

\section{IFN-based regimens}

Most of the new direct acting antivirals and host-targeted agents in development are currently tested as part of triple combinations with pegylated IFN- $\alpha$ and ribavirin. The results of Phase II trials have been encouraging with other NS3-4A protease inhibitors, such as TMC435 or BI201335 (currently in Phase III evaluation), the NS5A inhibitor daclatasvir (BMS-790052), or the cyclophilin inhibitor alisporivir (DEBIO-025, currently in Phase III evaluation), with sustained virological response rates of the same order as those with telaprevir and boceprevir [22-25]. Results of trials with two non-nucleoside inhibitors, filibuvir and tegobuvir, have been disappointing. However, this result cannot be generalized to the wider group of non-nucleoside inhibitors of HCV RNAdependent RNA polymerase, as it seems to be essentially the result of the modest antiviral efficacy of the two individual compounds. Results are awaited with other drugs, tested in ongoing clinical trials. As with telaprevir and boceprevir, the response to IFN and ribavirin is a key determinant of the final outcome of therapy. It is too early to say whether the effect of IFN responsiveness will be attenuated when drugs with a high barrier to resistance are used in combination with pegylated IFN- $\alpha$ and ribavirin.

Interest was recently raised about quadruple combination treatment regimens that combine pegylated IFN- $\alpha$, ribavirin, and two direct acting antivirals belonging to different drug classes without cross-resistance. In a study in patients who previously experienced a null response to pegylated IFN- $\alpha$ and ribavirin, 10 out of 10 patients receiving a quadruple combination including both daclatasvir (an NS5A inhibitor) and asunaprevir (an NS3-4A protease inhibitor) showed a sustained virological response [26]. The number of patients in this study was too small to draw firm conclusions, and it also remains to be established whether two drugs with a low barrier to resistance do better in combination with pegylated IFN- $\alpha$ and ribavirin than one drug with a high barrier to resistance, or whether quadruple combinations may be further improved by including at least one drug with a high barrier to resistance.

\section{All-oral, IFN-free regimens}

Enthusiasm about IFN-free regimens has recently risen dramatically with reports of sustained virological response rates of the order of $100 \%$ in small groups of patients treated with one or two direct acting antivirals alone, with or without ribavirin. What is known about IFN-free regimens can be summarized as follows: (a) the combination of two oral drugs with a low barrier to resistance results in early virological breakthroughs due to the selection of viral populations that are resistant to both drugs [26-28]; (b) ribavirin accelerates HCV clearance in combination with direct acting antivirals in the absence of IFN and is useful for shortening treatment duration and preventing post-treatment relapses [27]; (c) the use of a nucleotide analogue (PSI-7977) with ribavirin in patients infected with HCV genotypes 2 and 3 [29], or of a combination of an NS3-4A protease inhibitor (asunaprevir) and an NS5A inhibitor (daclatasvir) in patients infected with genotype $1 \mathrm{~b}$ [30], a population in which daclatasvir has a reasonably high barrier to resistance, yielded $100 \%$ sustained virological response rates in small groups of patients. 
Overall, these results provide a proof-of-concept that HCV infection can be cured by an all-oral IFN-free treatment regimen within 12 to 24 weeks and that very high sustained virological response rates can be achieved with drugs or drug combinations that have a high barrier to resistance. They strongly suggest that the IFN era is coming to an end in hepatitis $C$ therapy, although this end cannot yet be precisely dated. Further results are awaited that will allow the establishment of an ideal all-oral IFN treatment regimen for patients with chronic HCV infection.

\section{Conclusion}

A new standard-of-care is now available for patients infected with HCV genotype 1, based on the triple combination of pegylated IFN- $\alpha$, ribavirin, and either telaprevir or boceprevir. However, these new therapies are associated with increased costs, additional side effects and more complex treatment strategies, whereas pegylated IFN- $\alpha$ and ribavirin remain the standard treatment for all other genotypes, as well as in resource-limited settings where the cost of these new therapies cannot be afforded. A universal, cost-effective, well-tolerated all-oral first-line treatment regimen is needed and will most likely be available within a few years, when more is known about the ideal combination of drugs and the optimal doses and duration. Nevertheless, antiviral therapy is not the solution to definitively eradicate HCV infection, most of the 120-130 million chronic carriers live in areas where screening, cost and access to care preclude the use of these novel therapies. An efficient prophylactic vaccine is still urgently needed. This will be the next, and probably last, challenge of the HCV story.

\section{Abbreviations}

HCV, hepatitis C virus; IFN, interferon.

\section{Competing interests}

The author has received research grants from Gilead and Roche/Genentech. He has served as an advisor for Abbott, Achillion, Anadys, Biotica, Boehringer-Ingelheim, BristolMyers Squibb, DebioPharm, Gen-Probe, Gilead, GlaxoSmithKline, Idenix, Inhibitex, Janssen-Cilag, MadausRottapharm, Sanofi-Aventis, Schering-Plough/Merck, Novartis, Pfizer, Roche/Genentech, Vertex and Virco.

\section{References}

I. Choo QL, Kuo G, Weiner AJ, Overby LR, Bradley DW, Houghton M: Isolation of a cDNA clone derived from a blood-borne non-A, non-B viral hepatitis genome. Science 1989, 244:359-62.

FI000 Factor 6

Evaluated by Jean-Michel Pawlotsky 16 Jan 2012

2. Alter HJ, Purcell RH, Shih JW, Melpolder JC, Houghton M, Choo QL, Kuo G: Detection of antibody to hepatitis $C$ virus in prospectively followed transfusion recipients with acute and chronic non-A, non-B hepatitis. N Engl 」 Med 1989, 321:1494-I500.

FI000 Factor 6

Evaluated by Jean-Michel Pawlotsky 16 Jan 2012

3. Colombo M, Kuo G, Choo QL, Donato MF, Del Ninno E, Tommasini MA, Dioguardi N, Houghton M: Prevalence of antibodies to hepatitis $\mathbf{C}$ virus in Italian patients with hepatocellular carcinoma. Lancet 1989, 2:1006-8.

FI000 Factor 6

Evaluated by Jean-Michel Pawlotsky 16 Jan 2012

4. van der Poel CL, Reesink HW, Lelie PN, Leentvaar-Kuypers A, Choo QL, Kuo G, Houghton M: Anti-hepatitis C antibodies and non-A, non-B post-transfusion hepatitis in The Netherlands. Lancet 1989, 2:297-8.

FI000 Factor 6

Evaluated by Jean-Michel Pawlotsky 16 Jan 2012

5. Seeff LB: Natural history of chronic hepatitis C. Hepatology 2002, 36:S35-46.

6. Global Burden Of Hepatitis C Working Group: Global burden of disease (GBD) for hepatitis C. J Clin Pharmacol 2004, 44:20-29.

FI000 Factor 6

Evaluated by Jean-Michel Pawlotsky 20 Jan 2012

7. Simmonds P, Bukh J, Combet C, Deleage G, Enomoto N, Feinstone S, Halfon P, Inchauspé G, Kuiken C, Maertens G, Mizokami M, Murphy DG, Okamoto H, Pawlotsky JM, Penin F, Sablon E, Shin-I T, Stuyver LJ, Thiel HJ, Viazov S, Weiner AJ, Widell A: Consensus proposals for a unified system of nomenclature of hepatitis C virus genotypes. Hepatology 2005, 42:962-73.

8. Fried MW, Shiffman ML, Reddy KR, Smith C, Marinos G, Goncales FL Jr., Haussinger D, Diago M, Carosi G, Dhumeaux D, Craxi A, Lin A, Hoffman J, Yu J: Peginterferon alfa-2a plus ribavirin for chronic hepatitis $\mathbf{C}$ virus infection. $N$ Engl J Med 2002, 347:975-82.

9. Hadziyannis SJ, Sette HJ, Morgan TR, Balan V, Diago M, Marcellin P, Ramadori G, Bodenheimer H Jr, Bernstein D, Rizzetto M, Zeuzem S, Pockros PJ, Lin A, Ackrill AM; PEGASYS International Study Group: Peginterferon-alpha2a and ribavirin combination therapy in chronic hepatitis C: a randomized study of treatment duration and ribavirin dose. Ann Intern Med 2002, 140:346-55.

10. Manns MP, McHutchison JG, Gordon SC, Rustgi VK, Shiffman M, Reindollar R, Goodman ZD, Koury K, Ling M, Albrecht JK: Peginterferon alfa-2b plus ribavirin compared with interferon alfa-2b plus ribavirin for initial treatment of chronic hepatitis C: a randomised trial. Lancet 200I, 358:958-65.

II. Lindenbach $B D$, Rice $C M$ : Unravelling hepatitis C virus replication from genome to function. Nature 2005, 436:933-8.

12. Pawlotsky JM, Chevaliez S, McHutchison JG: The hepatitis $\mathbf{C}$ virus life cycle as a target for new antiviral therapies. Gastroenterology 2007, I32: 1979-98.

13. Pawlotsky JM: Treatment failure and resistance with directacting antiviral drugs against hepatitis $\mathbf{C}$ virus. Hepatology 20 I , 53:1742-5I.

14. Hezode C, Forestier N, Dusheiko G, Ferenci P, Pol S, Goeser T, Bronowicki JP, Bourlière M, Gharakhanian S, Bengtsson L, McNair L, George S, Kieffer T, Kwong A, Kauffman RS, Alam J, Pawlotsky JM, Zeuzem S; PROVE2 Study Team: Telaprevir and peginterferon with or without ribavirin for chronic $\mathrm{HCV}$ infection. $N$ Engl J Med 2009, 360:1839-50.

15. Bacon BR, Gordon SC, Lawitz E, Marcellin P, Vierling JM, Zeuzem S, Poordad F, Goodman ZD, Sings HL, Boparai N, Burroughs M, Brass CA, Albrecht JK, Esteban R; HCV RESPOND-2 Investigators: Boceprevir for previously treated chronic HCV genotype I infection. N Engl J Med 20II, 364:I207-I7.

FI000 Factor 6

Evaluated by Jean-Michel Pawlotsky 16 Jan 2012 
16. Poordad F, McCone J Jr., Bacon BR, Bruno S, Manns MP, Sulkowski MS, Jacobson IM, Reddy KR, Goodman ZD, Boparai N, DiNubile MJ, Sniukiene V, Brass CA, Albrecht JK, Bronowicki JP; SPRINT-2 Investigators: Boceprevir for untreated chronic HCV genotype I infection. N Engl J Med 20II, 364: I I95-206.

FI000 Factor 6

Evaluated by Jean-Michel Pawlotsky 16 Jan 2012

17. Zeuzem S, Andreone P, Pol S, Lawitz E, Diago M, Roberts S, Focaccia R, Younossi Z, Foster GR, Horban A, Ferenci P, Nevens F, Müllhaupt B, Pockros P, Terg R, Shouval D, van Hoek B, Weiland O, Van Heeswijk R, De Meyer S, Luo D, Boogaerts G, Polo R, Picchio G, Beumont M; REALIZE Study Team: Telaprevir for retreatment of HCV infection. N Engl J Med 20II, 364:2417-28.

FI000 Factor 6

Evaluated by Jean-Michel Pawlotsky 16 Jan 2012

18. Jacobson IM, McHutchison JG, Dusheiko G, Di Bisceglie AM, Reddy KR, Bzowej NH, Marcellin P, Muir AJ, Ferenci P, Flisiak R, George J, Rizzetto M, Shouval D, Sola R, Terg RA, Yoshida EM, Adda N, Bengtsson L, Sankoh AJ, Kieffer TL, George S, Kauffman RS, Zeuzem S; ADVANCE Study Team: Telaprevir for previously untreated chronic hepatitis $\mathbf{C}$ virus infection. $N$ Engl J Med 20II, 364:2405-16

FI000 Factor 6

Evaluated by Jean-Michel Pawlotsky 16 Jan 2012

19. Sullivan JC, De Meyer S, Bartels DJ, Dierynck I, Zhang E, Spanks J, Tigges A, Adda N, Martin EC, Jacobson IM, Sherman KE, Zeuzem S, Picchio G, Kieffer TL: Evolution of treatment-emergent resistant variants in telaprevir phase 3 clinical trials. J Hepatol 20II, 54(Suppl I):S4.

20. Sherman KE, Sulkowski MS, Zoulim F, Alberti A, Wei LJ, Sullivan J, Martin EC, Tara L Kieffer, Sandra De Meyer, Gaston Picchio, Camilla $S$ Graham; Stefan Zeuzem on behalf of the EXTEND Study Team: Follow-up of SVR durability and viral resistance in patients with chronic hepatitis $C$ treated with telaprevir-based regimens: interim analysis of the EXTEND study. Hepatology 2011 , 54(Suppl):485A.

21. Zeuzem S, Barnard RJ, Howe JA, Ogert RA, Ralston R, Boparai N, Brass CA, Albrecht JK, Burroughs M, Sniukiene V, Poordad F, Gordon SC, Jacobson IM: Boceprevir resistance-associated variants (RAVs) are observed more frequently in HCV (GTI)-infected patients with poor response to peginterferon alfa-2b/ribavirin. J Hepatol 20II, 54(Suppl I):S4.

22. Fried MW, Buti M, Dore GJ, Flisiak R, Ferenci P, Jacobson IM, Marcellin P, Manns MP, Nikitin I, Poordad FF, Sherman M, Zeuzem S, Lenz $O$, Peeters $M$, Sekar V, De Smedt GD: TMC435 in combination with peginterferon and ribavirin in treatmentnaive HCV genotype I patients: final analysis of the PILLAR Phase Ilb study. Hepatology 20I I, 54(Suppl): I 429A.

23. Dieterich D, Asselah T, Guyader D, Berg T, Ceausu E, Preotescu L, Schuchmann M, Mauss S, Ratziu V, Ferenci P, Larrey G, Maieron A, Biermer M, Stern JO, Scherer J, Kubiak R, Boecher WO: SILEN-C3: treatment for I 2 or 24 weeks with B|20I335 combined with peginterferon alfa-2a and ribavirin (P/R) in treatment-naive patients with chronic genotype I HCV infection. Hepatology 20I I, 54(Suppl):378A.

24. Hezode C, Hirschfield GM, Ghesquiere W, Sievert W, RodriguezTorres M, Shafran SD, Thuluvath PJ, Tatum HA, Waked I, Esmat GE, Lawitz E, Rustgi VK, Pol S, Weis N, Pockros P, Bourliere M, Serfaty L, Vierling JM, Fried MW, Weiland O, Brunetto MR, Everson GT, Zeuzem S, Kwo PY, Sulkowski MS, Yin PD, Diva UA, Hughes EA, Wind-Rotolo M, Scnittman SM: BMS-790052, a NS5A replication complex inhibitor, combined with peginterferon alfa-2a and ribavirin in treatment-naive $\mathrm{HCV}$ genotype I or 4 patients: phase 2b Al4440 I0 study interim week 12 results. Hepatology 20II, 54(Suppl):474A.

25. Flisiak R, Pawlotsky JM, Crabbé R, Calistru PI, Kryczka W, Haussinger D, Mazzella G, Romero M, Purcea D, Vuagniaux G, Bao W, Avila C, Zeuzem S: Once daily alisporivir (DEB 025) plus PegIFN alfa-2a/ribavirin results in superior sustained virologic response (SVR24) in chronic hepatitis C genotype I treatment naive patients. J Hepatol 20I I, 54(Suppl I):S2.

26. Lok AS, Gardiner GF, Lawitz E, Martorell C, Everson GT, Ghalib R, Reindollar R, Rustgi V, McPhee F, Wind-Rotolo M, Persson A, Zhu K, Dimitrova DI, Eley T, Guo T, Grasela DM, Pasquinelli C: Preliminary study of two antiviral agents for hepatitis C genotype I. N Engl J Med 2012, 366:216-24.

27. Zeuzem S, Buggisch P, Agarwal K, Manns MP, Marcellin P, Foster GR, Sereni D, Klinker H, Moreno C, Zarksi JP, Horsmans Y, Shelton M, West S, Zong J, Harris J, McHutchison J, Lee W, Delaney W, Oldach D: Dual, triple, and quadruple combination treatment with a protease inhibitor (GS-9256) and a polymerase inhibitor (GS-9190) alone and in combination with ribavirin (RBV) or PegIFN/RBV for up to 28 days in treatment-naïve, genotype I HCV subjects. Hepatology 2010, 52(suppl):400A.

28. Lok AS, Gardiner DF, Lawitz E, Martorell C, Everson GT, Ghalib RH, Reindollar R, Rustgi V, Wendelburg P, Zhu K, Shah V, Sherman D, McPhee F, Wind-Rotolo M, Bifano M, Eley T, Guo T, Persson A, Hindes R, Grasela D, Pasquinelli C: Combination therapy with BMS-790052 and BMS-650032 alone or with PegIFN/RBV results in undetectable HCV RNA through 12 weeks of therapy in HCV genotype I null responders. Hepatology 2010, 52(Suppl):877A.

29. Gane EJ, Stedman CA, Hyland RH, Sorensen RD, Symonds WT, Hindes R, Berrey MM: Once daily PSI-7977 plus RBV: pegylated interferon alfa not required for complete rapid viral response in treatment-naive patients with HCV GT2 or GT3. Hepatology 20II, 54(Suppl I):377A.

30. Chayama K, Takahashi S, Kawakami Y, Ikeda K, Suzuki F, Toyota J, Karino Y, Ohmura T, Ishikawa H, Watanabe H, Guo T, McPhee F, Hughes EA, Kumada $\mathrm{H}$ : Dual oral combination therapy with the NS5A inhibitor BMS-790052 and the NS3 protease inhibitor BMS-650032 achieved $90 \%$ sustained virologic response (SVRI2) in HCV genotype Ib-infected null responders. Hepatology 20I I, 54(Suppl): I 428A. 